\title{
Investigation of the deposition and emission of mercury in arctic snow during an atmospheric mercury depletion event
}

\author{
Kelsey P. Johnson, ${ }^{1}$ Joel D. Blum, ${ }^{1}$ Gerald J. Keeler, ${ }^{2}$ and Thomas A. Douglas ${ }^{3}$ \\ Received 30 January 2008; revised 19 May 2008; accepted 17 June 2008; published 5 September 2008.
}

[1] Mechanisms of air-snow exchange of mercury $(\mathrm{Hg})$ during and after atmospheric mercury depletion events (AMDEs) remain poorly constrained and this has limited our understanding of the arctic $\mathrm{Hg}$ cycle. We measured the $\mathrm{Hg}$ concentrations of surface snow through time and carried out flux chamber experiments during AMDE and non-AMDE conditions in the spring of 2006 near Barrow, Alaska. Clear skies, low-velocity onshore winds, and a stable boundary layer characterized the meteorology during this AMDE. Surface snow Hg concentrations (upper $1 \mathrm{~cm}$ ) increased throughout a 9-day AMDE from background levels $(4.1-15.5 \mathrm{ng} / \mathrm{L})$ to elevated levels (147 and $237 \mathrm{ng} / \mathrm{L})$ at two sampling sites and returned to near-baseline values within 2 days of AMDE cessation. The Hg concentrations of core samples from the full snowpack did not increase significantly during the AMDE and demonstrate that the $\mathrm{Hg}$ enhancement of surface snow resulted from deposition of atmospheric $\mathrm{Hg}$ to surface snow. We estimate that complete deposition of background $\mathrm{Hg}$ to a height of 200-450 $\mathrm{m}$ in the near-surface troposphere could account for the $\mathrm{Hg}$ gains to surface snow during this event. Snow incubated in field-based flux chambers emitted 4 to $7 \%$ of its total $\mathrm{Hg}$ content within 1 day and may represent an upper limit for the photo-reduction rate of "easily" reducible $\mathrm{Hg}$ in snow under post-AMDE conditions. Full-column snow core samples collected in the late springtime have comparable $\mathrm{Hg}$ loads to those observed during the AMDE season and imply that a significant fraction of the $\mathrm{Hg}$ deposited during the 3-month AMDE season was retained until snowmelt at this location.

Citation: Johnson, K. P., J. D. Blum, G. J. Keeler, and T. A. Douglas (2008), Investigation of the deposition and emission of mercury in arctic snow during an atmospheric mercury depletion event, J. Geophys. Res., 113, D17304, doi:10.1029/2008JD009893.

\section{Introduction}

[2] Projected changes in the Earth's climate may alter global contaminant transport pathways [Macdonald et al., 2005] and could enhance mercury (Hg) deposition to highlatitude ecosystems by changing the nature, amount and timing of precipitation [Law and Stohl, 2007]. Following deposition to terrestrial ecosystems from the atmosphere, $\mathrm{Hg}$ can be transformed into its more toxic form, methylmercury, which strongly biomagnifies in aquatic food webs and presents a major source of human exposure to $\mathrm{Hg}$ [Magos and Clarkson, 2006]. This provides a potential transport pathway to humans in coastal populations reliant upon fish and piscivorous mammals for subsistence [Wheatley and Paradis, 1995].

[3] The biogeochemical cycle of $\mathrm{Hg}$ is complex (see review by Fitzgerald and Lamborg [2003]) because $\mathrm{Hg}$

\footnotetext{
${ }^{1}$ Department of Geological Sciences, University of Michigan, Ann Arbor, Michigan, USA.

${ }^{2}$ University of Michigan Air Quality Laboratory, Ann Arbor, Michigan, USA.

${ }^{3}$ Biogeochemical Sciences Branch, U.S. Army Cold Regions Research and Engineering Laboratory, Fort Wainwright, Alaska, USA.

Copyright 2008 by the American Geophysical Union. 0148-0227/08/2008JD009893
}

has two common redox states in the environment. Gaseous elemental mercury (GEM, $\mathrm{Hg}^{0}$ ) undergoes long-range, atmospheric transport and has an atmospheric background concentration of 1.3 to $1.7 \mathrm{ng} / \mathrm{m}^{3}$ [Ebinghaus et al., 2002; Slemr et al., 2003]. Reactive gaseous mercury (RGM, $\mathrm{Hg}^{2+}$ ) and particulate mercury $\left(\mathrm{Hg}_{\mathrm{P}}\right)$ are procedurally defined atmospheric Hg species [Landis et al., 2002] with shorter atmospheric lifetimes and variable background concentrations typically orders of magnitude less than $\mathrm{Hg}^{0}$.

[4] Both ozone and $\mathrm{Hg}^{0}$ depletions of the near-surface, polar atmosphere are photochemical phenomena associated with polar sunrise. Tropospheric ozone depletion events were first reported in Barrow, Alaska, in 1986 [Oltmans and Komhyr, 1986] and atmospheric mercury depletion events (AMDEs) were first observed at Alert, Canada, in 1995 [Schroeder et al., 1998]. During tropospheric ozone depletion events, $\mathrm{O}_{3}$ mixing ratios drop from background values of 25 to $35 \mathrm{ppb}(\mathrm{v})$ to nearly $0 \mathrm{ppb}(\mathrm{v})$. AMDEs occur seasonally in high-latitude, coastal regions during the 3-month interval following polar sunrise. During AMDEs, $\mathrm{Hg}^{0}$ concentrations drop well below $1 \mathrm{ng} / \mathrm{m}^{3}$ for periods of hours to days concurrently with ozone depletions. Numerous studies have documented AMDEs in the Arctic [Schroeder et al., 1998; Lu et al., 2001; Berg et al., 2003; Steffen et al., 2003, 2005; Ferrari et al., 2005; Gauchard et al., 2005], the Antarctic [Ebinghaus et al., 2002; Sprovieri et al., 2002] 
and the subarctic [Kirk et al., 2006; see review by Steffen et al., 2007]. Similar to stratospheric ozone depletion, AMDEs result from photochemical reactions involving halogen oxidants and heterogeneous reaction sites on ice crystals (see review by Barrie and Platt [1997]). Unlike stratospheric ozone depletion, atomic $\mathrm{Br}$ rather than $\mathrm{Cl}$ is thought to be the dominant halogen destroying tropospheric $\mathrm{O}_{3}$ and oxidizing $\mathrm{Hg}^{0}$ during AMDEs [Barrie et al., 1988; Simpson et al., 2005 and references therein]. Photolabile $\mathrm{Br}$ gases are transferred from the ocean to the atmosphere via "bromine explosions" in the springtime as brines are rejected from freezing seawater [Simpson et al., 2007].

[5] Mercury concentrations in arctic surface snow have been observed to increase dramatically during AMDEs [Lindberg et al., 2002] and this $\mathrm{Hg}$ becomes increasingly bio-available during snowmelt [Scott, 2001]. As much as $90 \%$ of the $\mathrm{Hg}$ content of a snowpack may enter the meltwater reservoir upon snowmelt [Dommergue et al., 2003]. Kinetic modeling studies estimate gross AMDE inputs of $\mathrm{Hg}$ to the arctic of 100 tons/year [Ariya et al., 2004] and 119 tons/year [Skov et al., 2004]. However more detailed studies reveal that $\mathrm{Hg}$ concentrations in snow vary temporally and spatially [Douglas et al., 2005] and this variability is a function of snow provenance [Douglas et al., 2008]. In addition, mass balance models do not adequately consider $\mathrm{Hg}$ loss from the snowpack by (photo)reduction and subsequent $\mathrm{Hg}^{0}$ emission. Annual emission estimates of $\mathrm{Hg}$ from snow in arctic regions vary widely and our understanding of the net ecosystem $\mathrm{Hg}$ load is highly uncertain.

[6] The objective of this study is to better constrain mechanisms of air-snow $\mathrm{Hg}$ exchange during and after AMDE conditions. We used high temporal resolution snow and air sampling to monitor $\mathrm{Hg}$ gain and loss from seasonal snow at an arctic coastal location near Barrow, Alaska $\left[71.32^{\circ} \mathrm{N}, 156.6^{\circ} \mathrm{W}\right]$, during a single, 9-day AMDE. Barrow is distant from major pollution point sources and is known to experience AMDEs [Lindberg et al., 2001, 2002; Brooks et al., 2006]. Our field study spanned 13 March to 4 April 2006 with additional samples collected throughout the spring and during snowmelt. Mercury concentrations from a suite of surface snow samples are reported in a time series from two locations before, during, and after the mercury depletion event. Flux chamber experiments were designed to quantify $\mathrm{Hg}$ emission under closely monitored conditions. Several experiments were performed and included those under ambient conditions, under attenuated UV radiation conditions, and under artificially enhanced snow $\mathrm{Hg}$ concentration.

\section{Methods}

\subsection{Cleaning Procedures}

[7] Snow samples were collected in FEP Teflon bottles cleaned by the following procedure. Bottles were first rinsed with acetone, washed in warm water with Citrinox soap, rinsed five times with water purified by reverse osmosis, and soaked in a hot $3.5 \% \mathrm{HNO}_{3}$ bath for 6 hours. In a clean room, bottles were rinsed 5 times with $18.2 \mathrm{M} \Omega-\mathrm{cm}$ deionized water (DIW), filled with $1 \% \mathrm{BrCl}$ for at least 12 hours, and finally rinsed five times with DIW. Mercury concentrations were measured on $10 \%$ of the bottles prior to shipment and show that there is no bottle contribution to the samples. Flux chambers were washed with $5 \% \mathrm{HCl}$ and were dried and bagged in a clean room prior to shipment to the field site. A polyethylene shovel used to fill chambers with surface snow and PVC tubing used to collect snowpack cores were washed in $10 \% \mathrm{HCl}$ in a laboratory prior to use and were rinsed with DIW in a field laboratory between sample collections.

\subsection{Snow Sampling Procedures and Study Site}

[8] Three types of snow samples were collected in this study and their $\mathrm{Hg}$ concentrations are referred to as $\mathrm{Hg}_{\text {surface }}, \mathrm{Hg}_{\text {core, }}$ and $\mathrm{Hg}_{\text {snowfall }}$. Surface samples were collected from the upper $1 \mathrm{~cm}$ of the snow surface and represent recently blowing snow or stagnant surface snow $\left(\mathrm{Hg}_{\text {surface }}\right)$. Core samples were collected periodically with a 5-cm-diameter PVC pipe and represent the combination of two to four vertical cores of the full snow column into a $2.2 \mathrm{~L}$ FEP Teflon bottle $\left(\mathrm{Hg}_{\text {core }}\right)$. Snowfall samples were collected in Pyrex trays elevated on a rack $1.5 \mathrm{~m}$ above the snowpack surface. Saltating snow grains rarely get above $0.5 \mathrm{~m}$ during wind transport [Pomeroy and Gray, 1990], and therefore the samples collected from elevated glass trays represent precipitation and/or condensation rime ( $\left.\mathrm{Hg}_{\text {snowfall }}\right)$.

[9] Care was taken to approach sampling locations from the downwind direction to prevent contamination. Either a polystyrene scoop washed in $10 \% \mathrm{HCl}$ or the lip of the acidcleaned sampling bottle was used to transfer snow into FEP Teflon collection bottles. All samples remained frozen, in the dark, and triple bagged in lock-seal plastic bags during shipment to the University of Michigan for chemical analysis.

[10] Site 1 was on a low relief, gently rolling landscape typical of the region and is located $7 \mathrm{~km}$ northwest of Barrow and $2.5 \mathrm{~km}$ southeast of the Arctic Coast. Sampling occurred each day between 08:45 and 17:00 Alaska Standard Time (GMT -9 hours; AST). Morning samples were collected during a narrower time interval between 08:45 and 09:40 AST from 23 March through 31 March. Surface samples were collected daily between 13 March and 2 April and on 27 April, 20 May, and 31 May. Snow cores were collected on 23, 26, and 29 March and 1 April and later in the spring season on 27 April and 31 May. Snowfall/ condensation rime samples were collected each day that new snow was present in the elevated collection trays: 15, 16, 19, 20, 21, 22, and 25 March and 1 and 2 April.

[11] Site 2 was a snow drift on the downwind side of a wooden snow fence located $7 \mathrm{~km}$ northwest of Barrow and $1.3 \mathrm{~km}$ southeast of the coast. During the interval from 22 March through 1 April 2006, surface snow was collected each morning prior to exposure to direct sunlight (between 7:25 and 10:40 AST) and each evening after exposure to roughly 12 hours of sunlight (between 20:15 and 22:10 AST). Surface snow used to fill flux chambers (described below) was collected at this location during morning sampling.

\subsection{Flux Chamber Experiments}

[12] Several flux chamber experiments were performed and are summarized in Table 1. Chambers were filled with snow to a height of $8-12 \mathrm{~cm}$ and weighed before being sealed in a plastic bag, covered with opaque plastic, trans- 
Table 1. Summary and Description of Flux Chamber Experiments

\begin{tabular}{|c|c|c|c|c|}
\hline Experiment no. & Date & Time & Conditions & Description (Snow Collection Date) \\
\hline 1 & 25 March & $10: 10-22: 00$ & ambient & Ambient TGM vs. chamber blank \\
\hline 2 & 22 March & $08: 05-21: 10$ & ambient & $\begin{array}{l}\text { Snow overlying sea ice }(3 / 20) \text {. Underwent some compaction } \\
\text { during transport }\end{array}$ \\
\hline 3 & 23 March & $10: 45-21: 10$ & ambient & Surface snow from Site 2 (3/23), AMDE conditions \\
\hline 4 & 24 March & $10: 05-21: 10$ & ambient & Surface snow from Site $2(3 / 24)$, AMDE conditions \\
\hline 5 & 27 March & $10: 40-21: 10$ & ambient & Surface snow from Site $2(3 / 27)$, AMDE conditions \\
\hline 6 & 31 March & $10: 45-19: 10$ & ambient & Surface snow from Site $2(3 / 31)$, non-AMDE conditions \\
\hline 7 & 29 March & $10: 05-21: 10$ & UV attenuated & $\begin{array}{c}\text { Surface snow from Site } 2(3 / 29) \text {, AMDE conditions. Chamber } 7 \text { a received } \\
\text { UV-attenuated radiation; Chamber } 7 b \text { received ambient UV radiation }\end{array}$ \\
\hline 8 & 30 March & $09: 20-21: 40$ & $\begin{array}{l}\text { artificially } \\
\text { high } \mathrm{Hg}_{\text {(surface) }}\end{array}$ & $\begin{array}{l}\mathrm{Hg} \text { standard was applied to chamber formerly incubated as } 7 \mathrm{a}(3 / 29) \\
\mathrm{Hg}_{(\text {surface) }} \text { was more heterogeneous than in other experiments }\end{array}$ \\
\hline
\end{tabular}

ported on foot to an outdoor incubation location at the Barrow Arctic Science Consortium (BASC), and installed within 1 hour. The chambers were designed to simulate natural chemical conditions by allowing ambient air containing photo-labile oxidants such as $\mathrm{Br}_{2}, \mathrm{H}_{2} \mathrm{O}_{2}$, and $\mathrm{O}_{3}$ to enter the chamber through an inlet tube (Figure 1). The chamber inlet was therefore unfiltered and consisted of a $50-\mathrm{cm}$ long, unheated Teflon tube $(0.64-\mathrm{mm}$ outer diameter) covered with opaque plastic. This inlet was designed to capture most incoming $\mathrm{Hg}^{2+}$ by sorption to its walls without altering the chemical constituents entering the chamber. Flux chambers consisted of rectangular, translucent, $40 \mathrm{~L}$ polypropylene boxes. A flat piece of $1.27 \mathrm{~cm}$ thick polycarbonate served as a removable chamber lid and had two $28 \mathrm{~cm} \times 30.5 \mathrm{~cm}$ holes removed as windows. The inner surface of the lid was lined with 5 mil PFA Teflon film to allow full-spectrum light transmittance through the windows (Figure 2).

[13] Experiment 1 measured a procedural chamber blank, which exceeded ambient atmospheric $\mathrm{Hg}$ values by less that $1 \mathrm{ng} \mathrm{TGM} / \mathrm{m}^{3}$ (Figure 7). The mean blank from chamber material during daytime hours was $0.22 \mathrm{ng} / \mathrm{m}^{2} /$ hour and was therefore insignificant compared with concentrations observed during incubation experiments. Experiment 2 used snow that was collected from a snowpack overlying sea ice and stored in dark, subfreezing conditions for 2 days prior to installation. Surface snow was shoveled into a doublelayered polyethylene bag, transported to the research station, homogenized, and transferred into a chamber base. Experiments 3, 4, 5, and 6 utilized snow collected from Site 2 under ambient light, temperature, and $\mathrm{Hg}_{\text {surface }}$ conditions. In experiments 3-7, surface snow was collected from Site 2 by shoveling directly into flux chambers. Visible alteration of the snow structure by warming or compression during this preparation was negligible and care was taken to minimize compaction, disturbance and sintering. Experiment 7 operated two identical chambers, one of which received UV-attenuated radiation (7a) while the other received ambient solar radiation (7b). After 1 day of incubation, chamber 7 a was opened and $9.8 \mathrm{~g}$ of a $170 \mu \mathrm{g} / \mathrm{L}$ solution of $\mathrm{Hg}$ in $0.001 \mathrm{M} \mathrm{HNO}_{3}$ was applied as a fine mist. This snow was homogenized, subsampled to determine the $\mathrm{Hg}$ concentration, and reinstalled as Experiment 8. Snow in experiment 8, therefore, underwent some structural metamorphism in response to stirring.

[14] Air from each chamber's headspace (10-20 L) was sampled continuously through two outlets at a rate of $2.5 \mathrm{~L} / \mathrm{min}$. Air was withdrawn from one port at a rate of $1.5 \mathrm{~L} / \mathrm{min}$, calibrated at $0^{\circ} \mathrm{C}$ and $1 \mathrm{~atm}$, and passed through heated Teflon tubing to a Tekran 2537A $\mathrm{Hg}$ analyzer (described below). Heating the outlet tube to $50-60^{\circ} \mathrm{C}$ allowed for quantification of the TGM flux by preventing condensation of water vapor and subsequent loss of $\mathrm{Hg}$ to the tubing walls. Air was withdrawn through the second outlet at a rate of $1.0 \mathrm{~L} / \mathrm{min}$ to increase the chamber's flushing rate. A Tekran Model 1110 Synchronized Two Port Sampling System was used to alternate total gaseous mercury (TGM) measurements between flux chambers and either a procedural blank or ambient air every third measurement (i.e., every 10 minutes). Consecutive measurements were averaged to yield a single data point every 10 minutes that alternated between chamber outlet $\left(\mathrm{C}_{\text {out }}\right)$ and either the ambient or ambient plus procedural blank measurement $\left(\mathrm{C}_{\text {in }}\right)$.

[15] TGM fluxes (F) were calculated for each experiment. The midpoint between consecutive blanks $\left(\mathrm{C}_{\text {in }}\right)$ was inter-

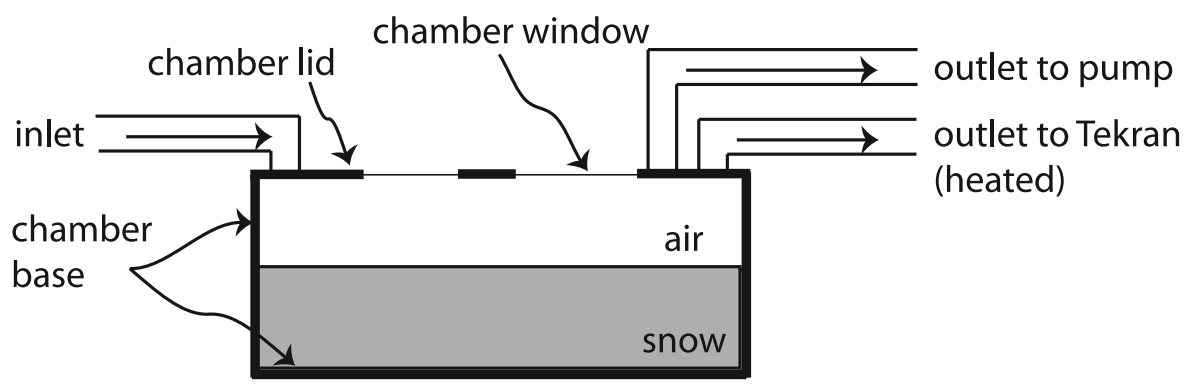

Figure 1. Flux chamber design. The chamber lid was composed of a 1/4-in. polycarbonate frame with $28 \times 30.5 \mathrm{~cm}$ windows cut in it. A 5-mil PFA Teflon film covered the inside of the chamber lid. Clamps and a gasket sealed the chamber lid to the chamber base. 


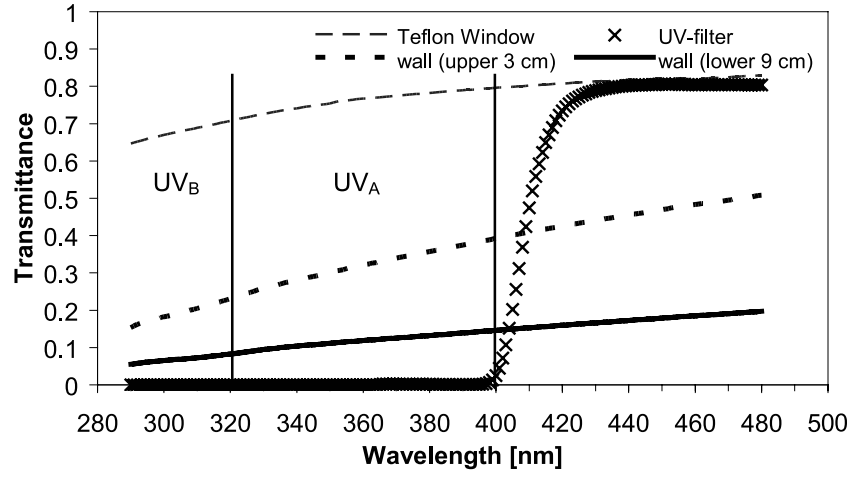

Figure 2. Transmittance properties of chamber materials.

polated and subtracted from the chamber measurement of the matching 20-minute time step $\left(\mathrm{C}_{\text {out }}\right)$. To calculate average hourly flux, the difference between $\mathrm{C}_{\text {out }}$ and $\mathrm{C}_{\text {in }}$ over the experiment sampling interval was multiplied by the flow rate $(Q=2.5 \mathrm{~L} / \mathrm{min})$ and a conversion factor $(k=$ $0.15 \mathrm{~m}^{3} / \mathrm{h}$ ) and divided by the surface area of snow within the chamber $\left(A=0.28 \mathrm{~m}^{2}\right)$. The starting times and duration of the flux chamber experiments varied somewhat due to difficult field logistics. To allow comparison between experiments, we calculated TGM emission for each experiment during the 3-hour interval of peak TGM flux: 12:3015:30. Daily and mid-day TGM fluxes are reported in units $\mathrm{ng} / \mathrm{m}^{2} /$ hour according to:

$$
\begin{gathered}
\mathrm{F}_{\text {hourly average }}=\left(\mathrm{C}_{\text {out }}-\mathrm{C}_{\text {in }}\right)_{\text {average }}^{*} Q^{*} k / A \\
\mathrm{~F}_{\text {mid hyp-day }}=\left(\mathrm{C}_{\text {out }}-\mathrm{C}_{\text {in }}\right)_{\text {average from } 12: 30-15: 30}^{*} Q^{*} k / A
\end{gathered}
$$

\subsection{Analytical Techniques}

[16] TGM was monitored in ambient air and from flux chambers using two Tekran model 2537A Mercury Vapor Analyzers. The Tekran 2537A operates two parallel gold traps which alternately collect and quantify TGM concentrations at 5-minute intervals using Cold Vapor Atomic Fluorescence Spectrometry. This provides an integrated sample every 5 minutes with units of $\mathrm{ng} \mathrm{Hg}$ per cubic meter of air. All $\mathrm{Hg}$ concentrations in snow are reported in ng $\mathrm{Hg}$ per liter of melted snow $\left(\mathrm{H}_{2} \mathrm{O}\right)$ and were quantified using a Nippon Instruments MA 2000 Atomic Absorption Spectrometer (AAS). Samples were acidified and oxidized to 1 vol. $\% \mathrm{BrCl}$ before thawing to preserve $\mathrm{Hg}^{2+}$ in solution. Excess $\mathrm{BrCl}$ was neutralized with $20 \mu \mathrm{L}$ concentrated hydroxylamine and aqueous $\mathrm{Hg}^{2+}$ was chemically reduced with $250 \mu \mathrm{L}$ each of $50 \% \mathrm{H}_{2} \mathrm{SO}_{4}$ and $\mathrm{SnCl}_{2}$ prepared according to EPA Method 1631e. Reduced $\mathrm{Hg}^{0}$ was purged from the sample solution, preconcentrated on an in-line gold trap and thermally desorbed into an AAS detector by heating to $650^{\circ} \mathrm{C}$. The NIST SRM-3133 $\mathrm{Hg}$ standard was used to cross-check the accuracy of a Nippon Instruments calibration standard. The limit of quantification of $1.0 \mathrm{ng} / \mathrm{L}$ is defined as $3 \mathrm{SD}$ of blanks run within analytical sessions. Replicate analyses of $100 \mathrm{ng} / \mathrm{L}$ standards yielded a $1 \mathrm{SD}$ analytical uncertainty of $\pm 2.5 \mathrm{ng} / \mathrm{L}$, while samples with concentrations less than $10 \mathrm{ng} / \mathrm{L}$ had a 1 SD uncertainty of $\pm 1 \mathrm{ng} / \mathrm{L}$. Duplicate analyses were performed on over half the samples and reproduced within $10 \%$. Field replicates collected for 21 snow samples had a mean relative standard deviation of $10 \%$. Procedural blanks of Teflon sample bottles averaged $1.2 \pm 0.5 \mathrm{ng} / \mathrm{L}$.

[17] Ozone was measured in ambient air using a TEI 49C UV photometric gas analyzer that sampled from an elevation of $2 \mathrm{~m}$ above the snow surface at the flux chamber incubation site. In addition, hourly averages of ozone mixing ratios were obtained from the NOAA Climate Monitoring and Diagnostic Laboratory Barrow Observatory (CMDL) located $8 \mathrm{~km}$ east of Barrow and $2 \mathrm{~km}$ from our study site at BASC at a height of $3 \mathrm{~m}$ above the ground surface.

[18] Ancillary meteorological data include hourly wind speed and direction data obtained from CMDL, Moderate Resolution Imaging Spectroradiometer (MODIS) images obtained from the University of Colorado, temperature, and diffuse light intensity. MODIS images provided insight into the location and morphology of sea-ice fractures (leads) off the Arctic Ocean Coast near Barrow and are not presented here. Temperature of ambient air and the air within flux chambers was recorded at 4 or 5-minute intervals using four temperature sensors (Onset Inc. HOBO Temperature Data Loggers). Diffuse light intensity was measured with three Onset Inc. HOBO Light Intensity Data Loggers (detection range: 0.01 to 10,000 lumens/ $\mathrm{ft}^{2}$; centered on $555 \mathrm{~nm})$.

\section{Results}

\subsection{Ozone Mixing Ratios, Atmospheric TGM and Meteorological Conditions}

[19] Ozone mixing ratios measured by CMDL are presented in Figures 3 and 6a and strongly correlate with ozone data measured at our study site $\left(r^{2}=0.96\right.$; Figure 3 inset). TGM concentrations were measured in ambient air using two Tekrans operated at a total of three locations during our study interval (Figure 5). There is a clear diurnal pattern of enhanced atmospheric TGM concentration occurring during the day. The ozone data set is continuous and allows a more clear demarcation of the AMDE interval than the TGM data set. AMDE conditions occurred for 9 days from predawn on 22 March to near midnight on 30 March 2006 in Barrow, Alaska, as defined by periods when hourly averages of CMDL ozone mixing ratios fell below $15 \mathrm{ppb}(\mathrm{v})$.

[20] Wind speed and direction varied bimodally between strong, continental winds during normal (non-AMDE) conditions and weak, coastal winds during AMDE conditions (Figure 4). Winds during AMDEs therefore passed over a marine halogen source that included seawater exposed in open ice leads and/or newly formed sea ice. During nonAMDE conditions, easterly winds averaged $7.8 \pm 2.9 \mathrm{~m} / \mathrm{s}$ (range $=0.3-13.7 \mathrm{~m} / \mathrm{s}$ ) and were associated with blowing snow events and the shearing of sea ice to create leads in the sea ice north and west of Barrow. On the basis of MODIS images, open leads were present roughly $15 \mathrm{~km}$ north and west of our study site from 11 to 21 March and again after 30 March. During AMDE conditions, westerly winds averaged $2.0 \pm 1.1 \mathrm{~m} / \mathrm{s}$ (range: 0 to $5.2 \mathrm{~m} / \mathrm{s}$ ) and mobilization of snow by wind was not observed. For example, footprints 


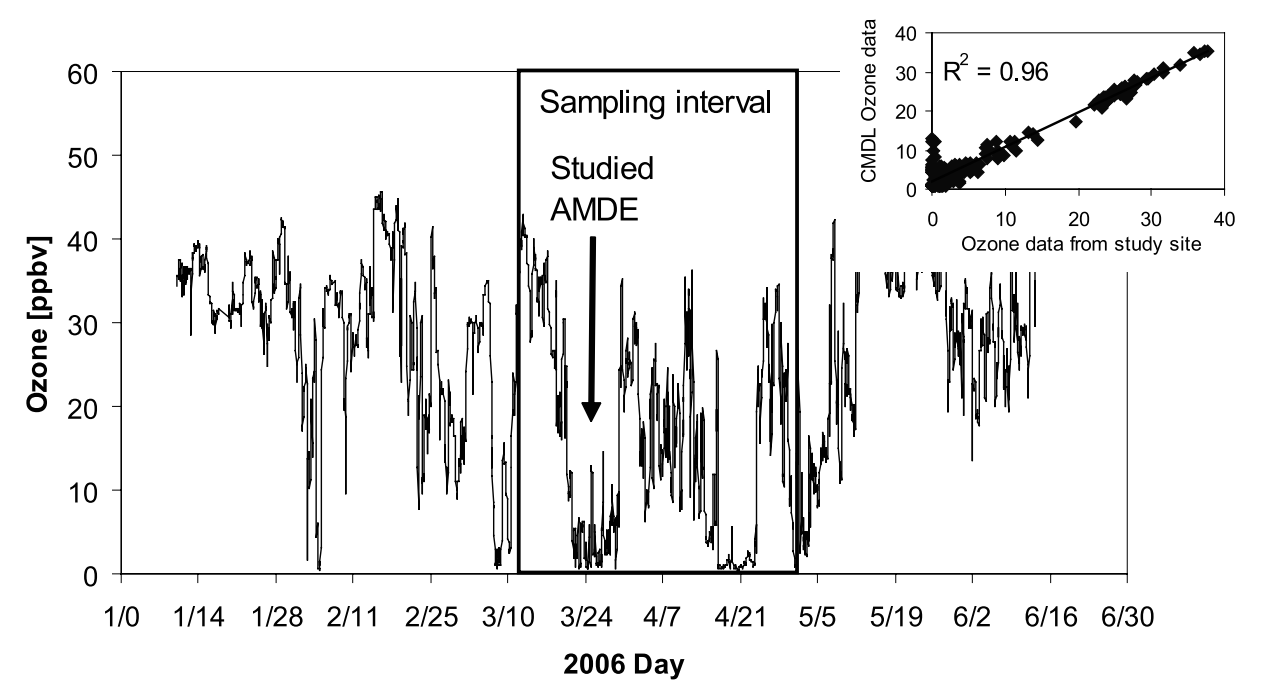

Figure 3. CMDL hourly ozone data from ambient air during the 2006 AMDE season. Inset shows the strong correlation between the ozone data from our study site and by that measured at CMDL $2 \mathrm{~km}$ away.

made during sample collection remained intact throughout the AMDE, whereas footprints during more windy, nonAMDE conditions were filled with saltating snow grains, scoured, and/or re-worked within minutes.

\subsection{Hg Concentrations in Surface Snow}

[21] Significant increases in surface snow $\mathrm{Hg}$ concentrations occurred during AMDE conditions at both sampling sites. At Site $1, \mathrm{Hg}_{\text {surface }}$ increased stepwise from background non-AMDE concentrations of $10 \mathrm{ng} / \mathrm{L}$ to concentrations over $200 \mathrm{ng} / \mathrm{L}$ within 3 days of the AMDE onset (Figure 6b). Specifically, $\mathrm{Hg}_{\text {surface }}$ at Site 1 increased from $9.5 \pm 3.4 \mathrm{ng} / \mathrm{L}$ (12-19 March) to elevated concentrations of $194 \pm 22 \mathrm{ng} / \mathrm{L}$ (23-30 March) before dropping to $53 \mathrm{ng} / \mathrm{L}$ (2 April) within 2 days of AMDE cessation. Subtracting the background $\mathrm{Hg}$ concentration of $10 \mathrm{ng} / \mathrm{L}$ from the elevated concentration range yields a surface snow increase of 162 $206 \mathrm{ng} / \mathrm{L}$. Assuming a snow density of 0.20 to $0.34 \mathrm{~g} / \mathrm{cm}^{3}$ typical in the arctic snowpack at Barrow [Sturm and Liston, 2003; this study], we estimate that deposition of 320 $700 \mathrm{ng} / \mathrm{m}^{2} \mathrm{Hg}$ occurred to the upper $1 \mathrm{~cm}$ of the snowpack at Site 1 during the observed AMDE.

[22] In contrast, $\mathrm{Hg}_{\text {surface }}$ at Site 2 increased gradually from $35 \mathrm{ng} / \mathrm{L}$ (22 March) to a peak of $147 \mathrm{ng} / \mathrm{L}$ (29 March) with an average daily increase of $16 \mathrm{ng} / \mathrm{L}$ (Figure 6b). Note that sample collection at Site 2 began during the first day of AMDE conditions and $\mathrm{Hg}_{\text {surface }}$ was probably already elevated above background. A diurnal pattern in $\mathrm{Hg}_{\text {surface }}$ is evident from "morning" and "evening" samples in which the $\mathrm{Hg}$ concentration increased overnight and either decreased or remained constant during the daytime (Figure 6b). Following the same density range as for Site 1, we estimate surface snow at Site 2 gained 220 to $380 \mathrm{ng} / \mathrm{m}^{2}$ $\mathrm{Hg}$ during this AMDE. During the AMDE, surface hoar (large feathery crystals that coat horizontal and vertical surfaces after intense radiation cooling [Colbeck, 1988]) was present on all snow surfaces surrounding Site 2 and also along irregular surfaces of an ice boulder in a sea ice pressure ridge that was sampled. Surface hoar crystals at Site 2 grew from initial lengths of $<0.5 \mathrm{~cm}$ (22 March) to over $3 \mathrm{~cm}$ by the end of the AMDE (31 March, morning only). Four samples of hoar frost collected from different faces of the sea ice pressure ridge contained $99 \pm 6.4 \mathrm{ng} / \mathrm{L}$ (29 March). Hoar frost may facilitate a different $\mathrm{Hg}$ deposition mechanism than that at Site 1 and may involve direct

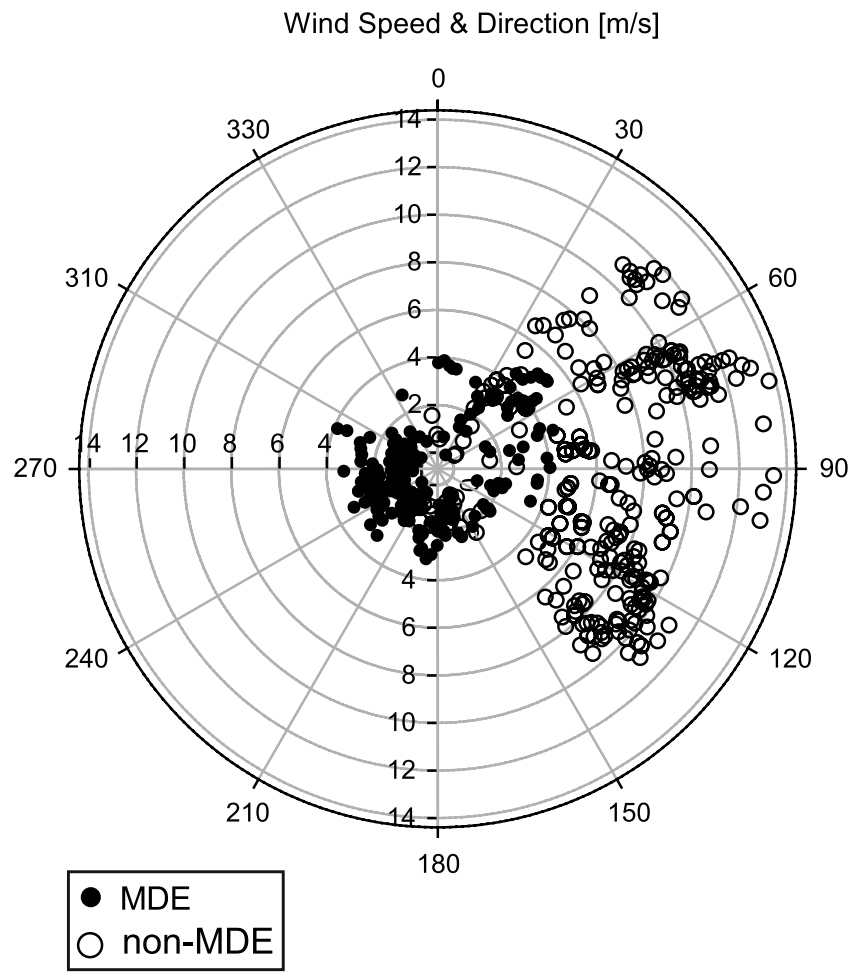

Figure 4. Wind speed $(\mathrm{m} / \mathrm{s})$ and direction during normal and AMDE conditions (which were defined based on $p \mathrm{O}_{3}$ ). Non-AMDE conditions span 3/13/06 0:00-3/21/06 7:00 and 3/31/06 15:00-4/3/06 23:00 when $\mathrm{pO}_{3}>15 \mathrm{ppb}(\mathrm{v})$. AMDE conditions span 3/22/06 03:00-3/30/06 23:00 when $p \mathrm{O}_{3}<15 \mathrm{ppb}(\mathrm{v})$. 
Table 2. TGM Emission Fluxes From Chamber Experiments

\begin{tabular}{|c|c|c|c|c|c|c|c|c|c|}
\hline Property & Units & $\begin{array}{c}\text { Experiment } \\
2 \\
\end{array}$ & $\begin{array}{c}\text { Experiment } \\
3 \\
\end{array}$ & $\begin{array}{c}\text { Experiment } \\
4 \\
\end{array}$ & $\begin{array}{c}\text { Experiment } \\
5 \\
\end{array}$ & $\begin{array}{c}\text { Experiment } \\
6 \\
\end{array}$ & $\begin{array}{c}\text { Experiment } \\
7 \mathrm{a} \\
\end{array}$ & $\begin{array}{c}\text { Experiment } \\
7 \mathrm{~b} \\
\end{array}$ & $\begin{array}{c}\text { Experiment } \\
8 \\
\end{array}$ \\
\hline Snow mass & $\mathrm{kg}$ & & & 3.1 & 5.4 & 2.7 & 4.0 & 3.7 & 3.6 \\
\hline Snow $[\mathrm{Hg}]$, initial & $\mathrm{ng} / \mathrm{L}$ & 55 & 65 & 74 & 118 & 82 & 147 & 147 & 422 \\
\hline Snow $[\mathrm{Hg}]$, final & $\mathrm{ng} / \mathrm{L}$ & 56 & 54 & 53 & & 87 & 98 & & 408 \\
\hline $\mathrm{Hg}$ in snow, initial & ng & & & 231 & 632 & 222 & 588 & 544 & 1518 \\
\hline Light intensity, mid-day avg. & $\mathrm{L} / \mathrm{sf} /$ hour & 713 & 744 & 965 & 811 & & 1310 & 1310 & 1310 \\
\hline Hourly TGM flux, average & $\mathrm{ng} / \mathrm{m}^{2} /$ hour & 3 & 5 & 5 & 13 & 3 & 7 & 9 & 21 \\
\hline Hourly TGM flux, mid-day & $\mathrm{ng} / \mathrm{m}^{2} /$ hour & 5.6 & 7.7 & 8.9 & 22 & 4.2 & 12 & 17 & 38 \\
\hline Daily TGM flux & $\mathrm{ng} / \mathrm{m}^{2} /$ day & 41 & 49 & 60 & 140 & 29 & 82 & 110 & 240 \\
\hline Daily $\mathrm{Hg}$ loss & ng/day & 12 & 14 & 17 & 39 & 8 & 23 & 31 & 67 \\
\hline Daily $\mathrm{Hg}$ loss & $\%$ & & & $7 \%$ & $6 \%$ & $4 \%$ & $4 \%$ & $6 \%$ & $4 \%$ \\
\hline
\end{tabular}

$\mathrm{Hg}^{2+}$ scavenging [Lahoutifard et al., 2006; Douglas et al., 2008]. After AMDE conditions ended, surface hoar crystals were quickly destroyed by wind erosion and $\mathrm{Hg}_{\text {surface }}$ diminished to near-initial levels within 2 days $(41 \mathrm{ng} / \mathrm{L}$ on 2 April).

[23] Freshly fallen snow and ice crystals contained the highest $\mathrm{Hg}$ concentrations observed in this study and previous studies at this location [Douglas et al., 2008] but added an insignificant thickness to the snowpack. Precipitation during AMDEs consisted of very fine-grained, diamond dust snowfall that added less than the height of the vertical error associated with collecting $1 \mathrm{~cm}$ of surface snow. Figure $6 \mathrm{c}$ reports values of $\mathrm{Hg}_{\text {snowfall }}$, which averaged $490 \pm 390 \mathrm{ng} / \mathrm{L}(n=9)$ and ranged from $21 \mathrm{ng} / \mathrm{L}(21 \mathrm{March})$ to $1100 \mathrm{ng} / \mathrm{L}$ (16 March). The highest snowfall concentrations $(>400 \mathrm{ng} / \mathrm{L})$ were observed during non-AMDE conditions while lower concentrations (i.e., $<100 \mathrm{ng} / \mathrm{L}$ ) were observed during AMDE conditions, with the exception of one sample that contained $360 \mathrm{ng} / \mathrm{L}$ (25 March).

\subsection{Snow Cores and Late Spring Samples}

[24] Full snowpack cores were collected from Site 1 during and after AMDE conditions to assess the total snowpack $\mathrm{Hg}$ content during and after the AMDE. The snowpack contained $7.6 \pm 0.6 \mathrm{ng} / \mathrm{L} \mathrm{Hg}$ during the AMDE $(n=3)$ with no significant difference from a core collected after the return to normal, non-AMDE conditions. Specifically, $\mathrm{Hg}_{\text {core }}$ values were $7.4 \mathrm{ng} / \mathrm{L}(23 \mathrm{March}), 7.1 \mathrm{ng} / \mathrm{L}$ (26 March), $8.3 \mathrm{ng} / \mathrm{L}$ (29 March), and 9.8 (1 April). Cumulative depths for respective cores were $0.54 \mathrm{~m}, 1.34 \mathrm{~m}$, $1.28 \mathrm{~m}, 1.49 \mathrm{~m}$ and snow water equivalences (SWE) for these four cores were $86,220,210$, and $230 \mathrm{~kg} / \mathrm{m}^{2}$. Corresponding Hg loads were $160,390,440$, and $560 \mathrm{ng} / \mathrm{m}^{2}$.

[25] Late springtime surface and core samples collected from Site 1 contained slightly lower $\mathrm{Hg}$ concentrations than during the highly monitored AMDE (Figure 6c). Specifically, late springtime $\mathrm{Hg}_{\text {surface }}$ concentrations were $45 \mathrm{ng} / \mathrm{L}$ (27 April), $10 \mathrm{ng} / \mathrm{L}$ (20 May), and 11 (31 May, upper $0.5 \mathrm{~cm}$ ). Full-column snow cores contained $2.5 \mathrm{ng} / \mathrm{L} \mathrm{Hg}$ $\left(200 \mathrm{~kg} / \mathrm{m}^{2}\right.$ SWE, 27 April) and $5.1 \mathrm{ng} / \mathrm{L}\left(130 \mathrm{~kg} / \mathrm{m}^{2}\right.$ SWE, 31 May), which corresponds to snowpack $\mathrm{Hg}$ loads of 250 and $340 \mathrm{ng} / \mathrm{m}^{2}$.

\subsection{Flux Chamber Experiments}

[26] Eight flux chamber experiments were performed to investigate TGM emission rates from natural, arctic snow under ambient temperature, ambient and attenuated UV radiation, and ambient and enhanced $\mathrm{Hg}$ concentrations. The goal of these experiments was to better understand photochemically driven processes of $\mathrm{Hg}^{0}$ oxidation and the subsequent re-emission of $\mathrm{Hg}$ from the snowpack. Specific procedures for each experiment are described above in Section 2 and are summarized in Table 1. Figure 7 presents TGM fluxes for each experiment (note different vertical scales); Table 2 summarizes $\mathrm{Hg}$ concentration and flux data for each experiment. TGM emission profiles always peaked shortly after solar noon and dropped below detection during hours of darkness. Some profiles deviated from bell-shaped curves as a result of low signal-to-noise ratios (Experiment 1), lids being briefly opened during chamber operation (Experiment 3), or temporary clogging of the outlet tubing (Experiment 6).

[27] The initial Hg concentration of snow within the flux chambers averaged $140 \mathrm{ng} / \mathrm{L}$ and ranged from 55 to $420 \mathrm{ng} / \mathrm{L}$. Flux chambers containing natural surface snow emitted TGM at an average rate of $6 \pm 4 \mathrm{ng} / \mathrm{m}^{2} /$ hour and ranged from 3 to $13 \mathrm{ng} / \mathrm{m}^{2} /$ hour. Within the 3 -hour, mid-day interval of maximum TGM emission, the TGM flux averaged $11 \pm$ $7 \mathrm{ng} / \mathrm{m}^{2} /$ hour and ranged from 4.2 to $22 \mathrm{ng} / \mathrm{m}^{2} /$ hour. The chamber experiment to which $1.7 \mu \mathrm{g}$ of $\mathrm{Hg}$ was added as liquid mist emitted a TGM average of $21 \mathrm{ng} / \mathrm{m}^{2} / \mathrm{hour}$ throughout the day and $38 \mathrm{ng} / \mathrm{m}^{2} /$ hour at mid-day.

[28] Transmittance properties of various chamber media used in our experiments are presented in Figure 2. The Teflon chamber window transmitted $65-71 \%$ of direct $U V_{B}$ $(290-320 \mathrm{~nm}), 71-80 \%$ of direct $\mathrm{UV}_{\mathrm{A}}(320-400 \mathrm{~nm})$, and $80-87 \%$ of direct visible light $(400-700 \mathrm{~nm})$ in laboratory tests, while a transmittance of diffuse light of $40 \%$ was measured in the field. Direct UV transmittance through the vertical chamber walls was a maximum of $40 \%$ during laboratory tests but was not measured in the field. We estimate that a maximum of $20 \%$ direct $\mathrm{UV}_{\mathrm{B}}$ and $30 \%$ direct $\mathrm{UV}_{\mathrm{A}}$ entered the chamber through its vertical walls during field experiments.

\section{Discussion}

\subsection{Factors Leading to Atmospheric Mercury Depletion Events}

[29] Meteorological and chemical data from this study are consistent with AMDE conditions resulting from local chemical oxidation [Lu et al., 2001] rather than influx of an air mass that was previously depleted in $\mathrm{Hg}$ [Gauchard et al., 2005]. Conditions of low wind velocity, a stable 
boundary layer (e.g., temperature inversion), ample sunlight, freezing temperatures and the availability of photolabile halogens near a high-latitude, coastal location characterize this AMDE. During the observed AMDE conditions, winds passed over re-freezing seawater before reaching the study site $(22-31 \mathrm{March})$, likely transporting halogens through the lower atmosphere where they are implicated in ozone destruction and $\mathrm{Hg}^{0}$ oxidation [Simpson et al., 2007]. The AMDE ended on 31 March when continental winds transported air masses containing background $\mathrm{O}_{3}$ and $\mathrm{Hg}^{0}$ to the study site.

[30] Ozone mixing ratios were a better tool than TGM concentrations for identifying AMDE conditions in this study. The CMDL ozone data set was more complete and more clearly demarcated the beginning and end of the AMDE interval than our TGM data. Additionally, TGM measurements do not equate to $\mathrm{Hg}^{0}$ measurements in general because reactive gaseous and particulate $\mathrm{Hg}$ species can episodically reach or exceed $1 \mathrm{ng} / \mathrm{m}^{3}$ during AMDEs [Lindberg et al., 2002; Kirk et al., 2006; this study]. A strong correlation between ozone and $\mathrm{Hg}^{0}$ between AMDE and non-AMDE periods throughout the polar springtime has been well documented [Schroeder et al., 1998; Ebinghaus et al., 2002; Skov et al., 2004].

\subsection{Exchange of $\mathbf{H g}$ Between Air and Surface Snow}

[31] Surface snow collected at both sampling sites contained elevated $\mathrm{Hg}$ levels during AMDE conditions (Figure 6b). The $\mathrm{Hg}$ concentration is reported in $\mathrm{ng} \mathrm{Hg}$ per Liter of melted snow, so an increase in the Hg concentration can be achieved by gaining $\mathrm{Hg}$, losing $\mathrm{H}_{2} \mathrm{O}$ or both. During AMDE conditions, horizontal mixing of surface snow was negligible and mobility of gaseous $\mathrm{Hg}^{0}$ through the snowpack by wind ventilation was also negligible at the observed wind velocities [Albert et al., 2002]. Therefore changes in $\mathrm{Hg}_{\text {surface }}$ represent vertical snow-atmosphere exchange of $\mathrm{Hg}$ and $\mathrm{H}_{2} \mathrm{O}$ during AMDE conditions. Highvelocity winds prominent during non-AMDE conditions vigorously mobilized snow and physically transported snow grains and associated $\mathrm{Hg}$. Therefore $\mathrm{Hg}_{\text {surface }}$ can be compared as a meaningful time series of vertical snowatmosphere exchange during this AMDE but not during normal, windy conditions.

[32] Deposition of background TGM from the atmosphere is believed to have caused the gains in $\mathrm{Hg}_{\text {surface }}$ that we observed during the studied AMDE. Atmospheric TGM levels dropped as $\mathrm{Hg}_{\text {surface }}$ at Site 1 increased to approximately 20 times background levels within 2 days of the onset of AMDE conditions. The observed deposition of $320-700 \mathrm{ng} / \mathrm{m}^{2} \mathrm{Hg}$ to the upper $1 \mathrm{~cm}$ of snow can be explained by oxidation and deposition of TGM available in the vertical boundary layer. However it is unclear whether this depletion is the result of near complete oxidation of the lowermost atmosphere or partial oxidation of a larger vertical profile. If background TGM from the lowermost boundary layer was completely oxidized and transferred to the snow surface, then we calculate that this TGM depletion would have extended to a height of 200 to $450 \mathrm{~m}$, assuming non-AMDE TGM concentrations were $1.6 \mathrm{ng} / \mathrm{m}^{3}$, AMDE TGM concentrations were $0 \mathrm{ng} / \mathrm{m}^{3}$ and the snow density ranged from 0.2 to $0.34 \mathrm{~g} / \mathrm{m}^{3}$ [Sturm and Liston, 2003]. Low wind velocity during the AMDE prevented an influx of

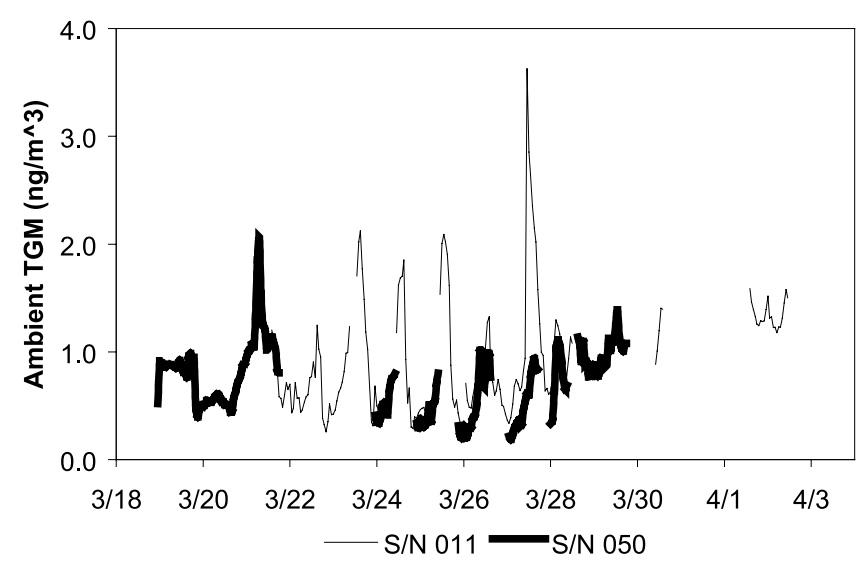

Figure 5. Ambient TGM data. S/N 050-BASC sampled air $2 \mathrm{~m}$ above the snow surface using a heated inlet from a window at the BASC laboratory. S/N 011 sampled TGM from a heated inlet tube from the snow surface at the flux chamber incubation site. S/N 050 was then moved to the same location as and sampling style as S/N 011. Diurnal cycles are evident and mid-day TGM spikes may result from $\mathrm{Hg}^{0}$ emission from the snow surface.

air containing higher TGM concentrations from regions not experiencing AMDE conditions. Our estimate of the height of TGM depletion is consistent with previous aircraft and sonde studies that constrained $\mathrm{Hg}$ depletion to an elevation of between 100 and $1000 \mathrm{~m}$ [Lindberg et al., 2002] and ozone and $\mathrm{Hg}$ depletion to a height of 300-400 m [Tackett et al., 2007 and references therein].

[33] Gradual increases in $\mathrm{Hg}_{\text {surface }}$ observed throughout the AMDE at Site 2 probably resulted from a different mechanism than that which caused the abrupt $\mathrm{Hg}_{\text {surface }}$ increase at Site 1. The presence of a snow fence created turbulence and reduced wind speed, forming a snow drift at Site 2 that was less representative of the regional snowpack than Site 1. Surface hoar at Site 2 may have scavenged atmospheric $\mathrm{Hg}$ via a mechanism relating to unusual atmospheric turbulence and $\mathrm{Hg}^{2+}$ scavenging during vapor phase crystal growth [Lahoutifard et al., 2006]. On 29 March, surface hoar from both Site 2 and a pressure ridge on the sea ice contained approximately half the $\mathrm{Hg}$ concentration of snow at Site 1. Surface hoar is thought to be capable of scavenging high levels of $\mathrm{Hg}^{2+}$ through vapor phase condensation during AMDEs [Douglas et al., 2005], but is a poor scavenger during low wind velocity conditions [Colbeck, 1988]. These properties may explain the gradual $\mathrm{Hg}_{\text {surface }}$ increase at Site 2 and the lower $\mathrm{Hg}_{\text {surface }}$ concentrations at both Site 2 and the pressure ridge with respect to Site 1.

[34] The increase in $\mathrm{Hg}_{\text {surface }}$ at Site 2 tended to occur at night in the absence of direct photochemical reactions. This means that the direction of net snow-atmosphere $\mathrm{Hg}$ exchange was emission during the day and deposition during the night. Similarly, atmospheric TGM concentrations and flux chamber TGM emission fluxes peaked during maximum solar intensity (Figures 5 and $6 \mathrm{~b}$ ) and further support the idea of net daytime $\mathrm{Hg}^{0}$ loss from the snowpack.

[35] The Hg concentration in snowfall was highest during non-AMDE conditions and probably resulted from scav- 

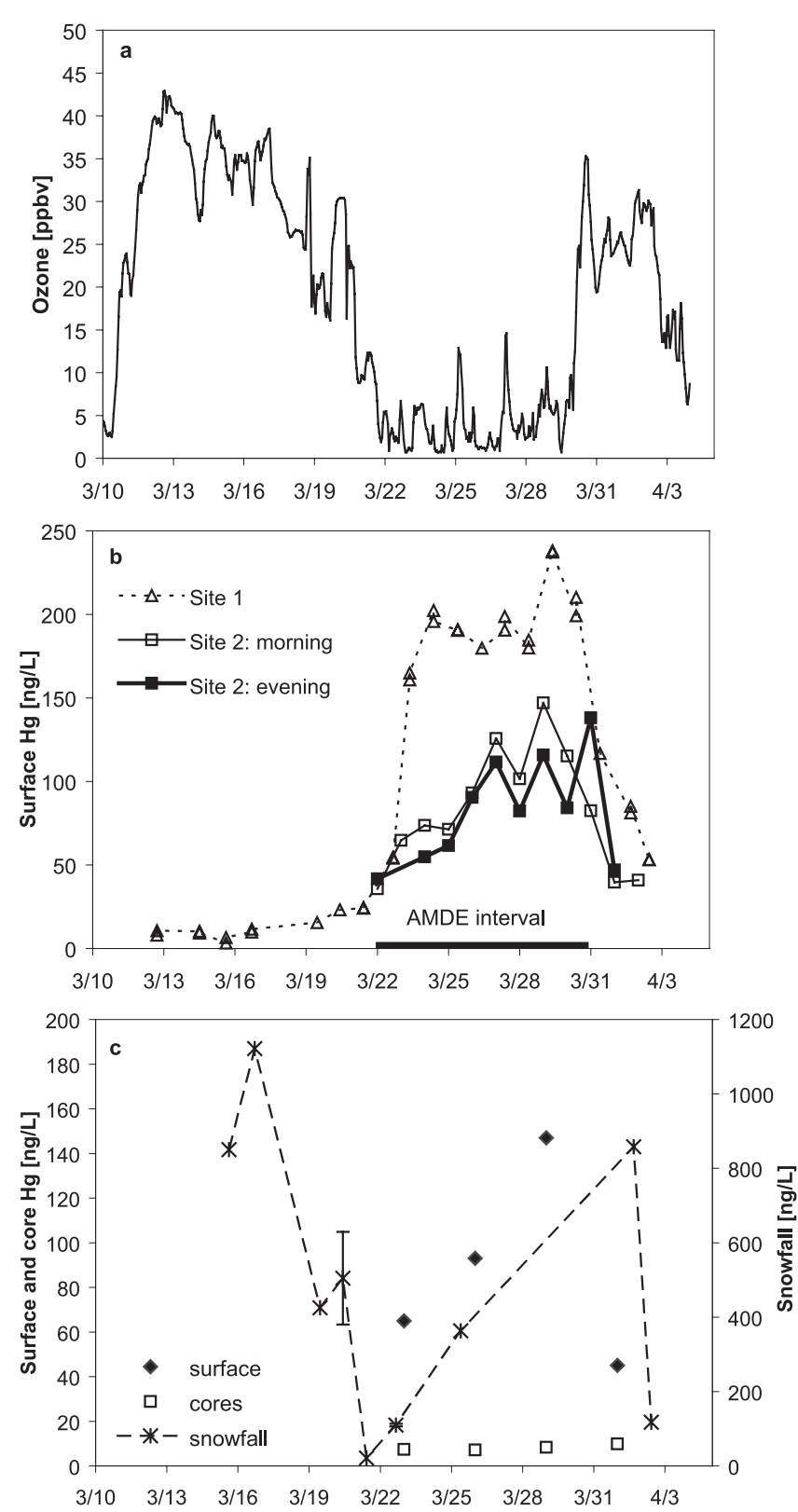

Figure 6. (a) Ozone mixing ratio during AMDE conditions. (b) Time series of $\mathrm{Hg}_{\text {surface }}$ (upper $1 \mathrm{~cm}$, melted) at both sampling locations. $\mathrm{Hg}_{\text {surface }}$ at Site 1 increases in surface snow during the AMDE. At site $2, \mathrm{Hg}_{\text {surface }}$ "morning" samples were collected in the morning after $\sim 12$ hours of darkness while "evening" samples were collected after $\sim 12$ hours of daylight. Data points are larger than $1 \sigma$ analytical precision; error bars indicate heterogeneity of replicate field samples. Horizontal bar demarcates AMDE interval. (c) Concentration of diamond dust snowfall, surface snow, and snow cores from Site 1 before, during and after AMDE conditions. Late springtime $\mathrm{Hg}_{\text {surface }}$ from Site 1 were $45 \mathrm{ng} / \mathrm{L}$ (27 April), $10 \mathrm{ng} / \mathrm{L}$ (20 May), and $11 \mathrm{ng} / \mathrm{L}$ (31 May, upper $0.5 \mathrm{~cm}$ ). $\mathrm{Hg}_{\text {core }}$ values from Site 1 were $2.5 \mathrm{ng} / \mathrm{L}$ (27 April) and $5.1 \mathrm{ng} / \mathrm{L}$ (31 May). Error bars indicate heterogeneity of field replicates; data points are larger than analytical uncertainty. enging of available RGM by snow crystals in the air column. The Hg-depleted boundary layer during AMDE conditions therefore had less $\mathrm{Hg}$ available for scavenging by snowfall than during normal conditions. The elevated $\mathrm{Hg}_{\text {snowfall }}$ sample collected during the AMDE (363 ng/L, 25 March) could be explained by scavenging of $\mathrm{Hg}$ recently re-emitted from the snow surface and re-oxidized in the near-surface atmosphere. After the return to non-AMDE conditions, one snowfall sample contained much less $\mathrm{Hg}$ than other non-AMDE samples (118 ng/L on 2 April) and was potentially diluted by deposition of a larger volume of moisture per unit of $\mathrm{Hg}$.

\subsection{Net Loading of $\mathbf{H g}$ to the Arctic Snowpack}

[36] We have documented rapid and significant increases in the $\mathrm{Hg}$ concentration of surface snow during AMDE conditions. To understand the arctic Hg cycle, it is essential to measure the portion of AMDE-derived $\mathrm{Hg}$ that remains in the snowpack and is available to be transferred to arctic ecosystems during snowmelt. The majority of snowfall forming the seasonal snowpack in Barrow falls prior to the AMDE season and contains low Hg levels. Surface and core data during the AMDE demonstrate that $\mathrm{Hg}$-enrichment was stratified with a high- $\mathrm{Hg}$ surface layer atop a low- $\mathrm{Hg}$ snowpack. Both $\mathrm{Hg}_{\text {surface }}$ and $\mathrm{Hg}_{\text {core }}$ values decreased between this AMDE and snowmelt in late May (Figure 6c), while snowpack loads of $\mathrm{Hg} / \mathrm{m}^{2}$ remained within the same range from the AMDE period up until the melt season. Variability in the load of $\mathrm{Hg} / \mathrm{m}^{2}$ may reflect both the heterogeneity in the lateral snow depth and air-snow $\mathrm{Hg}^{\mathrm{O}}$ exchange. Our data support the conclusion that not all AMDE-derived $\mathrm{Hg}$ was lost to the atmosphere as $\mathrm{Hg}^{0}$, but some became mixed throughout the uppermost snow layer that was mobilized by high wind velocities characteristic of non-AMDE conditions.

\subsection{Flux Chamber Experiments}

[37] Field-based flux chamber experiments more closely resemble natural processes than laboratory experiments because they can utilize fresh, minimally metamorphosed snow and are exposed to ambient sunlight, temperature and chemical constituents. However field-based experiments do not allow a high level of control over experimental conditions and do not perfectly replicate conditions experienced by the natural snowpack. For example, flux chambers were filled with surface snow rather than a representative fullcolumn snow sample, which enhanced the total Hg content within the chambers. Nonetheless, important mechanistic information about $\mathrm{Hg}$ emission can be gained from these experiments and is described below.

[38] Light intensity was the dominant control over the diurnal TGM emission pattern from snow while the $\mathrm{Hg}$ concentration of snow controlled the magnitude of the TGM flux. TGM peaked shortly after solar noon in the ambient atmosphere and all flux chamber experiments. During hours of darkness, TGM concentrations in the ambient atmosphere were lowest and in chamber experiments they were below detection (Figures 5 and 7). TGM emission rates were highly variable (note the different vertical scales in Figure 7) but were much less variable when normalized to the $\mathrm{Hg}$ content of the bulk snow in the chamber. Chambers consistently emitted 4 to $7 \%$ of their total $\mathrm{Hg}$ content within 

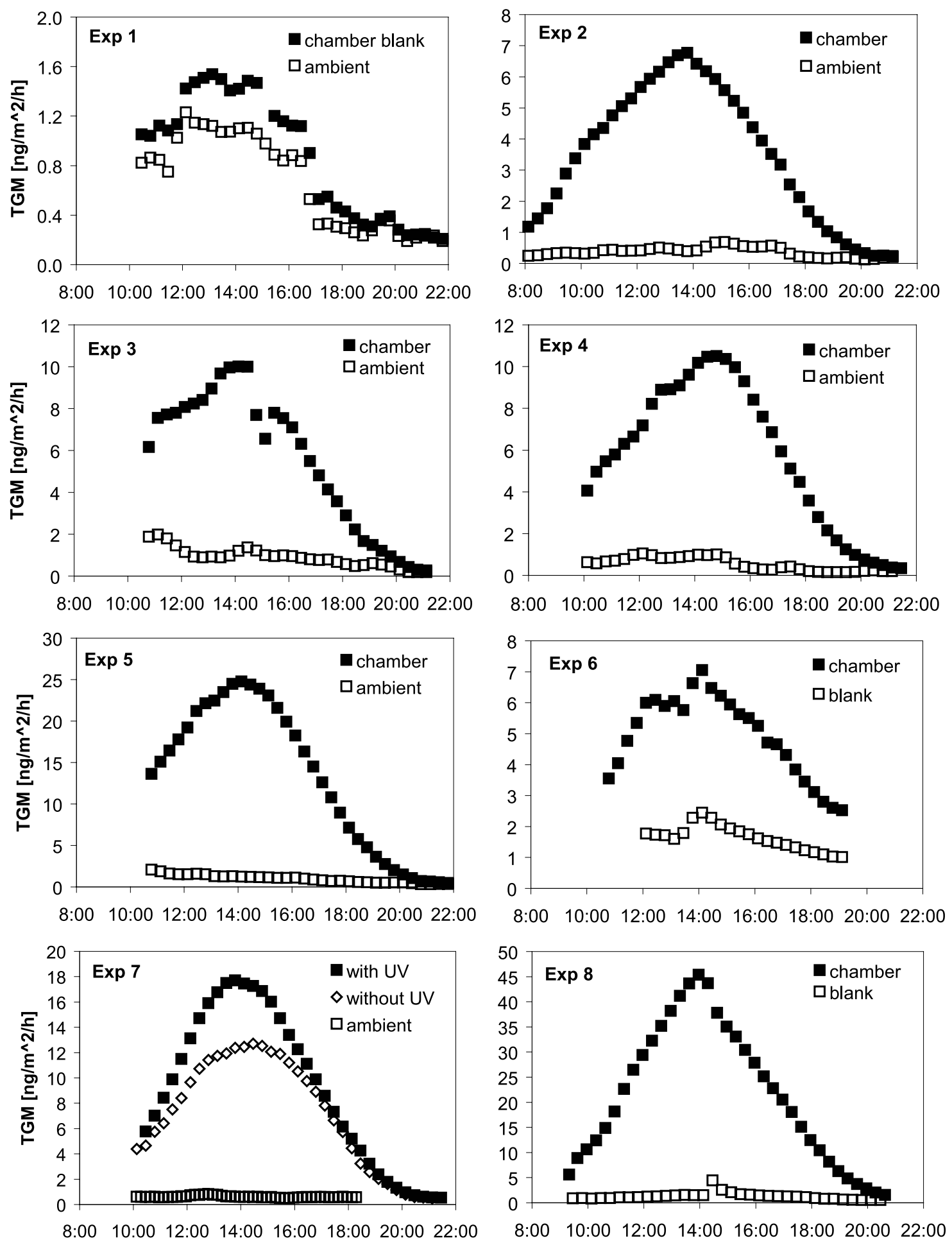

Figure 7. TGM flux profiles from eight flux chamber experiments. Experiment 1 measured $\mathrm{Hg}$ concentration from a chamber blank compared to ambient air; Experiments 2, 3, 4 and 5 operated during the AMDE under ambient conditions; Experiment 6 operated during non-AMDE conditions; Experiment 7 used two parallel chambers which received either UV-attenuated light (7a) or ambient light (7b); Experiment 8 incubated snow with artificially enhanced $\mathrm{Hg}$ content and operated during transition to non-AMDE conditions. See Table 1 for descriptions. 
1 day of exposure to sunlight, and $45 \% \pm 3 \%$ of this was emitted during the 3-hour mid-day interval. It is possible that these flux data represent the loss of only an "easily reducible" fraction of $\mathrm{Hg}$ in snow and represent an upper limit for the rate of photoreduction of $\mathrm{Hg}^{0}$ from arctic snow under similar conditions.

\section{Conclusion}

[39] Low-velocity onshore winds and stable boundary layer meteorology characterized AMDE conditions and resulted in rapid deposition of $\mathrm{Hg}^{2+}$ to the upper $1 \mathrm{~cm}$ of surface snow. When AMDE conditions ceased and strong continental winds returned, physical mixing distributed the enhanced $\mathrm{Hg}_{\text {surface }}$ throughout the mobile upper layer of the snowpack. Snow-atmosphere Hg exchange was dominated by photoreduction and emission of $\mathrm{Hg}^{0}$ during the day from both the natural snowpack and flux chamber experiments. Field-based flux chamber experiments typically lost $~ 5 \%$ of their $\mathrm{Hg}$ content within 1 day and may present a maximum rate of $\mathrm{Hg}$ loss via photoreduction of "easily reducible $\mathrm{Hg}$ " from natural snowpacks. Five to ten AMDEs typically occur each spring near Barrow and each may contribute $\mathrm{Hg}$ to the snowpack and eventually to terrestrial or aquatic ecosystems. Physical and chemical mechanisms of $\mathrm{Hg}$ deposition during AMDEs need to be better understood in order to assess how potential changes in meteorological conditions due to climatic warming in the arctic may affect atmospheric delivery of $\mathrm{Hg}$ to snow in the arctic coastal region. In addition, future experiments should be done to increase our understanding of how and when AMDE-derived Hg evades from snowpacks.

[40] Acknowledgments. This study was funded by the National Science Foundation Office of Polar Programs Grants ARC-0435989 and ARC-0435893. Special thanks to the Barrow Arctic Science Consortium, J. Barres, and UMAQL for technical expertise and J. Bier for field assistance. We thank B. Bergquist, M. Sturm, D. Perovich, W. Simpson, and L. Alvarez-Aviles for helpful discussions and two anonymous reviewers for comments that significantly improved the manuscript.

\section{References}

Albert, M. R., A. M. Grannas, J. Bottenheim, P. B. Shepson, and F. E. Perron (2002), Processes and properties of snow-air transfer in the high arctic with application to interstitial ozone at Alert, Canada, Atmos. Environ., 36, 2779-2787.

Ariya, P. A., et al. (2004), The arctic: A sink for mercury, Tellus, Ser. B Chem. Phys. Meteorol., 56, 397-403.

Barrie, L. A., J. W. Bottenheim, R. C. Schnell, P. J. Crutzen, and R. A. Rasmussen (1988), Ozone destruction and photochemical-reactions at polar sunrise in the lower arctic atmosphere, Nature, 334, 138-141.

Barrie, L., and U. Platt (1997), Arctic tropospheric chemistry: An overview, Tellus, Ser. B Chem. Phys. Meteorol., 49, 450-454.

Berg, T., S. Sekkesaeter, E. Steinnes, A. K. Valdal, and G. Wibetoe (2003), Springtime depletion of mercury in the European Arctic as observed at Svalbard, Sci. Total Environ., 304, 43-51.

Brooks, S. B., A. Saiz-Lopez, H. Skov, S. E. Lindberg, J. M. C. Plane, and M. E. Goodsite (2006), The mass balance of mercury in the springtime arctic environment, Geophys. Res. Lett., 33, L13812, doi:10.1029/ 2005GL025525.

Colbeck, S. C. (1988), On the micrometeorology of surface hoar growth on snow in mountainous area, Boundary Layer Meteorol., 44, 1-12.

Dommergue, A., C. P. Ferrari, P. A. Gauchard, C. F. Boutron, L. Poissant, M. Pilote, P. Jitaru, and F. C. Adams (2003), The fate of mercury species in a sub-arctic snowpack during snowmelt, Geophys. Res. Lett., 30(12), 1621, doi:10.1029/2003GL017308.

Douglas, T. A., M. Sturm, W. R. Simpson, S. Brooks, S. E. Lindberg, and D. K. Perovich (2005), Elevated mercury measured in snow and frost flowers near arctic sea ice leads, Geophys. Res. Lett., 32, L04502, doi:10.1029/2004GL022132.
Douglas, T. A., M. Sturm, W. R. Simpson, J. D. Blum, L. Alvarez-Aviles, G. J. Keeler, D. K. Perovich, A. Biswas, and K. Johnson (2008), Influence of snow and ice crystal formation and accumulation on mercury deposition to the arctic, Environ. Sci. Technol., 42, 1542-1551, doi:10.1021/es070502d.

Ebinghaus, R., H. H. Kock, C. Temme, J. W. Einax, A. G. Lowe, A. Richter, and W. H. Schroeder (2002), Antarctic springtime depletion of atmospheric mercury, Environ. Sci. Technol., 36, 1238-1244.

Ferrari, C. P., et al. (2005), Snow-to-air exchanges of mercury in an arctic seasonal snowpack in Ny-Alesund, Svalbard, Atmos. Environ., 39, $7633-7645$

Fitzgerald, W. F., and C. H. Lamborg (2003), Geochemistry of mercury in the environment, Treatise Geochem., 9, 107-148.

Gauchard, P. A., et al. (2005), Study of the origin of atmospheric mercury depletion events recorded in Ny-Alesund, Svalbard, spring 2003, Atmos. Environ., 39, 7620-7632.

Kirk, J. L., V. L. S. Louis, and M. J. Sharp (2006), Rapid reduction and reemission of mercury deposited into snowpacks during atmospheric mercury depletion events at Churchill, Manitoba, Canada, Environ. Sci. Technol., 40, 7590-7596.

Lahoutifard, N., L. Poissant, and S. L. Scott (2006), Scavenging of gaseous mercury by acidic snow at Kuujjuarapik, Northern Quebec, Sci. Total Environ., 355, 118-126, doi:10.1016/j.scitotenv.2005.02.021.

Landis, M. S., R. K. Stevens, F. Schaedlich, and E. M. Prestbo (2002), Development and characterization of an annular denuder methodology for the measurement of divalent inorganic reactive gaseous mercury in ambient air, Environ. Sci. Technol., 36, 3000-3009.

Law, K. S., and A. Stohl (2007), Arctic air pollution: Origins and impacts, Science, 315, 1537-1540, doi:10.1126/science.1137695.

Lindberg, S. E., S. Brooks, C.-J. Lin, K. Scott, T. Meyers, L. Chambers, M. Landis, and R. Stevens (2001), Formation of reactive gaseous mercury in the arctic: Evidence of oxidation of $\mathrm{Hg}^{0}$ to gas-phase $\mathrm{Hg}$-II compounds after arctic sunrise, Water Air Soil Pollut., 1, 295-302.

Lindberg, S. E., S. Brooks, C. J. Lin, K. J. Scott, M. S. Landis, R. K. Stevens, M. Goodsite, and A. Richter (2002), Dynamic oxidation of gaseous mercury in the arctic troposphere at polar sunrise, Environ. Sci. Technol., 36, 1245-1256.

Lu, J. Y., et al. (2001), Magnification of atmospheric mercury deposition to polar regions in springtime: The link to tropospheric ozone depletion chemistry, Geophys. Res. Lett., 28, 3219-3222.

Macdonald, R. W., T. Harner, and J. Fyfe (2005), Recent climate change in the arctic and its impact on contaminant pathways and interpretation of temporal trend data, Sci. Total Environ., 342, 5-86.

Magos, L., and T. W. Clarkson (2006), Overview of the clinical toxicity of mercury, Ann. Clin. Biochem., 43, 257-268.

Oltmans, S. J., and W. D. Komhyr (1986), Surface ozone distributions and variations from 1973-1984 measurements at the Noaa Geophysical Monitoring for climatic-change base-line observatories, J. Geophys. Res., 91, 5229-5236.

Pomeroy, J. W., and D. M. Gray (1990), Saltation of snow, Water Resour. Res., 26, 1583-1594.

Schroeder, W. H., K. G. Anlauf, L. A. Barrie, J. Y. Lu, A. Steffen, D. R. Schneeberger, and T. Berg (1998), Arctic springtime depletion of mercury, Nature, 394, 331-332.

Scott, K. J. (2001), Bioavailable mercury in arctic snow determined by a light-emitting mer-lux bioreporter, Arctic., 54, 92-95.

Simpson, W. R., L. Alvarez-Aviles, T. A. Douglas, M. Sturm, and F. Dominé (2005), Halogens in the coastal snow pack near Barrow, Alaska: Evidence for active bromine air-snow chemistry during springtime, Geophys. Res. Lett., 32, L04811, doi:10.1029/2004GL021748.

Simpson, W. R., D. Carlson, G. Honninger, T. A. Douglas, M. Sturm, D. Perovich, and U. Platt (2007), First-year sea-ice contact predicts bromine monoxide $(\mathrm{BrO})$ levels at Barrow, Alaska better than potential frost flower contact, Atmos. Chem. Phys., 7, 621-627.

Slemr, F., E. G. Brunke, R. Ebinghaus, C. Temme, J. Munthe, I. Wangberg, W. Schroeder, A. Steffen, and T. Berg (2003), Worldwide trend of atmospheric mercury since 1977, Geophys. Res. Lett., 30(10), 1516, doi:10.1029/2003GL016954.

Skov, H., J. H. Christensen, M. E. Goodsite, N. Z. Heidam, B. Jensen, P. Wahlin, and G. Geernaert (2004), Fate of elemental mercury in the arctic during atmospheric mercury depletion episodes and the load of atmospheric mercury to the arctic, Environ. Sci. Technol., 38, 2373-2382.

Sprovieri, F., N. Pirrone, I. M. Hedgecock, M. S. Landis, and R. K. Stevens (2002), Intensive atmospheric mercury measurements at Terra Nova Bay in Antarctica during November and December 2000, J. Geophys. Res., 107(D23), 4722, doi:10.1029/2002JD002057.

Steffen, A., W. H. Schroeder, G. Edwards, and C. Banic (2003), Mercury throughout polar sunrise 2002, J. Phys., IV, 107, 1267-1270.

Steffen, A., W. Schroeder, R. Macdonald, L. Poissant, and A. Konoplev (2005), Mercury in the arctic atmosphere: An analysis of eight years of 
measurements of GEM at Alert (Canada) and a comparison with observations at Amderma (Russia) and Kuujjuarapik (Canada), Sci. Total Environ., 342, 185-198.

Steffen, A., et al. (2007), A synthesis of atmospheric mercury depletion event chemistry linking atmosphere, snow and water, Atmos. Chem. Phys. Discuss., 7, 10,837-10,931.

Sturm, M., and G. E. Liston (2003), The snow cover on lakes of the Arctic Coastal Plain of Alaska, USA, J. Glaciol., 49, 370-380.

Tackett, P. J., A. E. Cavender, A. D. Keil, P. B. Shepson, J. W. Bottenheim, S. Morin, J. Deary, A. Steffen, and C. Doerge (2007), A study of the vertical scale of halogen chemistry in the arctic troposphere during Polar Sunrise at Barrow, Alaska, J. Geophys. Res., 112, D07306, doi:10.1029/ 2006JD007785.
Wheatley, B., and S. Paradis (1995), Exposure of Canadian aboriginal peoples to methylmercury, Water Air Soil Pollut., 80, 3-11.

J. D. Blum and K. P. Johnson, Department of Geological Sciences, University of Michigan, 1100 N. University Ave, Ann Arbor, MI 48109 , USA. (jdblum@umich.edu; kelseyjo@umich.edu)

T. A. Douglas, Biogeochemical Sciences Branch, U.S. Army Cold Regions Research and Engineering Laboratory, Fort Wainwright, AK, USA. (thomas.a. douglas@usace.army.mil)

G. J. Keeler, University of Michigan Air Quality Laboratory, Ann Arbor, MI 48109-2029, USA. (jkeeler@umich.edu) 